\title{
Environmental Scanning and Market Share of Selected Small and Medium Scale Enterprises in Lagos State, Nigeria
}

\author{
Aina, Sherifat. A. ${ }^{1} \&$ Egbuta, Olive $\mathbf{U}^{2}$ \\ 1-2 Business Administration \& Marketing Department \\ School of Management Sciences \\ Babcock University, Ilishan-Remo Ogun State
}

Nigeria

\begin{abstract}
Environmental scanning plays a critical role in ensuring that the performance of small and medium scale enterprises (SMEs) is improved and therefore serves as a good avenue for organisational sustainability. Earlier studies have focused on the challenges faced by SMEs Owners, managers, and employees but this study will concentrate on environmental scanning as they affect market shares of SMEs in Lagos State Nigeria. Due to a poor understanding of the factors that play out in the organisation, SMEs have experienced a decline in market share as they are unable to meet expected benchmarks; hence this paper assessed the effect of environmental scanning on the market share of selected SMEs in Lagos State, Nigeria.

A cross-sectional survey research design was adopted for the study. The population of this study consist of the owner/managers of SMEs located in Lagos State. The population was given as 8,396 sources provided by SMEDAN in conjunction with the Nigerian Bureau of Statistics (NBS). The sample of the study was determined from the population using the research advisors sampling table resulting in 370 also a $30 \%$ provision was made to take care of such discrepancies, making a total of 481 . A stratified and simple random sampling technique was employed, a well-structured and adapted questionnaire was administered to the respondents. 'Cronbach's alpha reliability coefficients ranged from 0.718 and 0.910 . Data were analysed using descriptive and inferential statistics.

The result of simple linear regression revealed that that environmental scanning has significant effect on market share $(\beta=0.513, \mathrm{t}$ $=10.782, \mathrm{R}^{2}=0.230, \mathrm{p}<0.05$ ).

The study recommends that the management team of the selected SMEs should ensure they adopt and implement proper environmental scanning to increase their market share. Also, the study recommends that SMEs should identify with their employees to a great extent so as to boost and improve creativity within the organisation.
\end{abstract}

Keywords: Environmental scanning, Market share, Organisational factors, Performance, Small and medium scale enterprises.

\section{INTRODUCTION}

Small and medium-scale enterprises (SMEs) have increasingly become a powerful and critical engine for both economic growth and social development, they are seen as change agents in today's rapidly growing, volatile and dynamic competitive business environment. SMEs are thought to be catalysts for a country's economic growth and development. Their efficiency, on the other hand, has been a source of concern for a variety of stakeholders, including academics, government managers, and regulatory agencies. Certain causes, such as a lack of awareness of the impact of organizational factors, have been blamed for their poor result other factors such as poor environmental awareness, lack of innovation, inadequate change management acceptance and unfavorable organizational culture.

Globally, different factors have been attributed to the poor performance among SMEs such as bad management, lack of necessary skills among managers and other staffs, low scale operations and lack of proper understanding of factors that play a critical role in the organisation (Neneh, \& Van Zyl, 2014) [1]. In the United States, as well as in Trinidad and Tobago, Small Business Enterprises (SBEs) are observed to impact a major influence on the economy. Their importance is well recognised to the extent that about $60 \%$ of the United State economy relies on the operations of small enterprises, while that of Trinidad and Tobago is observed at 55\%. Small and Medium Enterprises (SMEs) constitute the main focus in shaping business development policies in the European Union 
(EU) coming to the forefront of the world economy (Durguner, 2017; Kotane \& Kuzmina-Merlino, 2017; Melnichuk, 2017) [2-4]. The rising attention in SMEs has become more paramount since the economic impact of the 2007/2008 financial crisis on economies globally in the United States (US), China and Britain (Herath \& Mahmood, 2013) [5].

Despite the contributions of SMEs to every country's economy, they are facing different challenges that affects their performance generally (Rohrbeck \& Kum, 2018) [6]. For instance, In Iraq, Korea, Malaysia and other countries around the world, SMEs are faced with difficult challenges such as low human capacity, low economies of scale, poor market performance, declining profitability, inconsistency in government policies, access to financial support, poor sales and infrastructural inadequacies (Spacek \& Gatarik, 2017) [7]. In growing economies, small and medium enterprises in the sub-Saharan African region are faced with the constraints of technological backwardness, lack of adequate human resource skills, weak management (Nuryakin, 2016) [8].

Many SMEs in Africa are always facing the challenge of preventing turnover involving workers that have the required management knowledge and skills. Gbandi and Amissah (2014) had earlier noted that the contribution of SMEs to the Nigeria GDP has remained well below 5\% [9]. Affirming this statement, the Central Bank of Nigeria stated that there had been gross underperformance of the SMEs' sub-sector and this has undermined its contribution to the economic growth and development in Nigeria. There has been an increasing number of SMEs in Nigeria but their level of inadequate performance has affected their contribution to the enhancement of the country and the GDP due to different challenges such as low capitalisation, inadequate machinery and equipment as well as poor visualisation of what the future holds (Tahir \& Usman, 2019) [10]. The impact of COVID-19 on SMEs in the world remains an ongoing area of research to be explored because, there is less studies of attention on the effect of corona virus on SMEs with the main target on post-COVID-19 economic recovery (Amuda, 2020) [11]. Furthermore, COVID-19 has affected the decline in the oil price which is the main source of income and revenue to the Nigerian government. Most business sales since the outbreak of COVID-19 recorded low profit whereby most SMEs reported decline in the source of income. The outbreak of the corona virus pandemic in Nigeria has affected all facets of life such as: education, life style, social activities, governance, and economic orders.

Previous studies on the effect of environmental scanning on market share have centered on large companies, and limited research has been conducted on SMEs (Onodugo \& Ewurum, 2013; Ogini \& Adesanya, 2013) [12], 13]. Furthermore, limited studies exist on environmental scanning and Market Share of SMEs in Lagos State Nigeria (Olanipekun, Abioro, Akanni, Arulogun \& Rabiu, 2015) [14]. The number of under-performing SMEs are increasing as evidence supports that small business in Lagos, State does not live beyond five years (Agwu \& Emeti, 2014) [15]. Different factors have been identified to be responsible for the decline, and these are poor business environment, lack of managerial capability on the part of owners and managers, and also improper understanding of the measures and elements that exists in the environment of the business (Awiti, Oloko \& Rambo, 2017) [16]. Others factors can be the harsh, turbulent operating environment and an increasingly competitive environment which continues to prevail in Lagos State (Ukpabio, Oyebisi \& Siyanbola, 2019; Omodafe \& Nwaizugbo, 2017) [17], 18]. The SME sub-sector has been experiencing unprecedented issues in the globalised operating environment. In lights of the above, small and medium scale enterprises are recording low business turnover, loss of revenue and decline in market share. Due to a poor understanding of the factors that play out in the organisation, SMEs have experienced a decline in market share as they are unable to meet expected benchmarks (Monye \& Ibegbulem, 2018) [19]. There has been a reduction in the creativity level of the firms and competitive advantage is at high risk (Olugboyega, 2017) [20]. In addition to that, SMEs in Nigeria have not been able to achieve high and consistent effectiveness in their processes (Omodafe \& Nwaizugbo, 2017) [18].

\subsection{Literature Review}

This section discusses environmental scanning and market share. This section also covers the empirical and theoretical review.

Borges and Janissek-Muniz (2017) asserts that Environmental Scanning is characterized as the systematic monitoring of information about events that occur in the organization's external environment [21]. It's a piece of data that can help top management with their responsibilities of laying out the company's potential course of action. Similarly, McLean (2005) defined environmental scanning as a practice of identification, collection and generation of knowledge founded on external data to identify threats and opportunities in anticipation of them [22]. As a result, these strategies can be thought of as organizational factors, which are concerned with developing and sustaining a high-quality, cohesive, and practical organizational factors vision, as well as applying the insights gained in an organizationally useful manner (Tapinos, 2012) [23]. Environmental scanning deals with evaluating, monitoring and disseminating of information from the external and internal environment to important people within the corporation or organisation (Babatunde \& Adebisi, 2012) [24]. The environmental scanning process deals with gathering, analysing, and dispensing information for tactical or strategic reasons. The environmental scanning process involves gathering both objective and subjective data on the market conditions in which a company operates or is considering doing business (Babatunde \& Adebisi, 2012) [24]. 
One of the advantages of environmental scanning is that It improves decision-making because an organization's performance is dependent on its ability to make precise decisions. While one of its disadvantages is that it does not guarantee organisational effectiveness, it acts only as inputs in strategy development and testing.

Market share can be defined as a company's dominance over a portion of an industry is known as a market share. That is also the total revenue of a business that a company receives over a period of time. Simply divide the company's revenue for a given period by the amount of the industry's sales for the same period to get the percentage value of a market share (Bianchi, 2012) [25]. Market share is the percentage of the total sales volume in a market captured by a brand, product, or company. According to Okolo (2017), Market share is an indicator of a product's choice among customers over competing goods. A larger market share typically translates to higher sales, less effort to sell more, and a significant barrier to entry for new entrants. Instead of being the source of efficiency, market share is the result of it [26]. Differences in profitability among firms are due to higher efficiency. Efficient firms obtain a large market share and earn high profits induce a causal association between size and profitability (Woo \& Cooper, 2011) [27]. Market share is gained by companies whose goods or services provide superior value to their consumers. Firms that are better run and have a competitive edge expand faster than their competitors. Lower rates or better goods help firms with superior skill and organizational factors gain market share. (Caves \& Porter, 2010) [28].

Empirical works have shown several ways to improve market share in the organisation. Methodologically, according to the study of Éverton, Elton and Rossetto (2014) on environmental scanning, data was sourced with questionnaires that were both structured and unstructured to ensure analysis uses both qualitative and quantitative methods [29]. On the findings, the linkage existing between these two variables have been examined by various scholars (Onodugo \& Ewurum, 2013; Babtunde \& Adebisi, 2012) [12], [24]. The findings of Gupta (2013) revealed that there is a strong relationship between the business environment and the survival of the organisation. Therefore, the study recommends that this area should be well tackled to keep an organisation on an excellent platform to survive [30]. Furthermore, Gupta (2013), in his study of the environment and PEST analysis: an approach to the external business environment, established that environmental scanning has an impact on organisational survival. The study asserts that strategic environmental scanning helps effective organisational performance [30]. Furthermore, Babtunde and Adebisi (2012) recommends that organisation should periodically, strategically and continuously involve in strategic environmental scanning and pay strong attention to the threats and opportunities in the environment [24].

From theory, it could also be argued that environmental scanning can also drive market share. Dynamic capabilities theory (DCT) was developed by Teece, Pisano and Shuen (1997) [31]. It was defined as a way that explores how firms handle or bring about changes in their turbulent market climate through the reconfiguration of their firm-specific competencies into new competencies." (Teece, 2007) [32]. Some of the assumptions of the dynamic capabilities' theory include the fact that successful firms can demonstrate timely responsiveness to market dynamics. Furthermore, the theory asserts that the way businesses build firm-specific competencies to adapt to changing business environments is inextricably linked to the company's business process, market positions, and opportunities. Besides, the theory views competition in Schumpeterian terms, Furthermore, the theory takes a Schumpeterian approach to competition, in which companies are constantly attempting to develop new combinations and business rivals are constantly attempting to strengthen their competencies or mimic the competencies of their most qualified competitors (Teece, Pisano \& Shuen, 1997) [31].

This theory is relevant to this study because it sees organisational factors as a dynamic capability that allows an organisation to sense signals in the market or environment and reconfigure its resources to remain relevant in the future. Relating the Dynamic Capabilities approach to organisational factors and market share a fundamental challenge that needs to be cleared. The real challenge facing managers today bothers on how to make strategic decisions given the uncertainty of the future. Scholars have argued that analogy has many salutary effects: it facilitates strategic change by linking the past, present, and future (Kaplan \& Orlikowski, 2013) [33]; It aids companies in achieving superior positions by enabling managers to see prospects that are underserved because they are difficult to detect (Gavetti, 2012) [34]; and it provides the ability "to identify a superior course of action and foresee its consequences" (Gavetti \& Menon, 2016) [35]. In other words, confusion prompts comparison, allowing superior managerial judgment. The future's ambiguity is therefore clarified by the use of models and analogies. These models and analogies are made possible by using organisational factors as an approach to studying the environment through scanning to retrieve relevant insights and signals that will help the organisation to come up with innovations that will keep them relevant even in the nearest future.

The above framework can be reduced into the model as follows:

$\mathrm{MS}=\beta_{0}+\beta_{1} \mathrm{ES}+\mu_{\mathrm{i}}---------------------------------~ E q n 1$ 
From equation (1), MS is market share, ES is environmental scanning and ei is the exogenous variables which captures all other variables that could explain market share outside the model Equation 1.

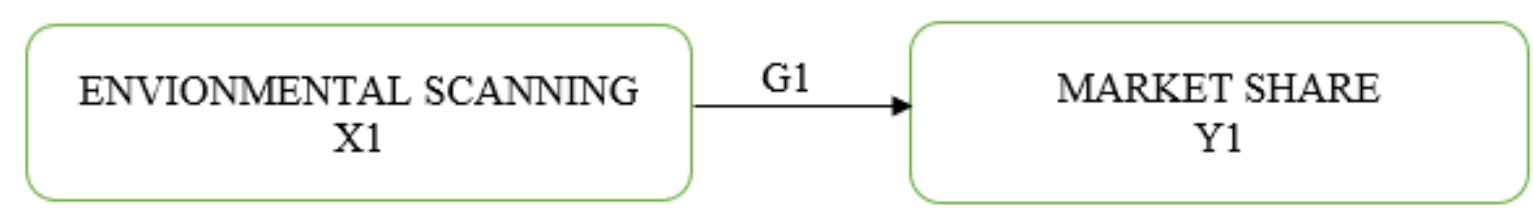

Fig 1- Environmental scanning and market share,

Source: Computed from literature (2021)

The figure above presents the conceptual model based upon the review of literature and it shows the effect of environmental scanning on market share.

\section{METHODOLOGY}

Cross sectional survey research design was adopted for the study. Cross-sectional survey research design was used because it involves collection of information from a given sample of population only once and at different location and at the same period of time. The population of this study consist of the owner/managers of small and medium scale enterprises located in Lagos State. The population was given as 8,396 sources provided by SMEDAN in conjunction with the Nigerian Bureau of Statistics (NBS). Sample of the study was determined from the population using the research advisors sampling table resulting in 370 also a $30 \%$ provision was made to take care of such discrepancies, making a total of 481. Stratified and simple random sampling technique was employed, well-structured and adapted questionnaire was administered to the respondents. The research instrument was validated and reliability was carried out using the Cronbach alpha analysis. The research instrument was validated and data gathered was analysed using descriptive statistics and simple linear regression analysis which was carried out with the aid of Statistical Package for Social Sciences (SPSS) version 23 software to test the hypotheses.

\section{DATA ANALYSIS, RESULTS AND DISCUSSION}

Various analyses were carried out in line with the main objective of the study, which is to determine the effect of environmental scanning on market share of selected SMEs in Lagos State, Nigeria. Data were analyzed using descriptive and inferential methods, namely percentage distribution, mean, and standard deviation. The descriptive statistics are as contained in Tables 1 and 2. 
Table 1: Descriptive Statistics on Environmental Scanning

Source: Field Survey Result (2020)

\begin{tabular}{|c|c|c|c|c|c|c|c|c|c|}
\hline Items & 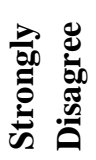 & 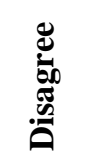 & 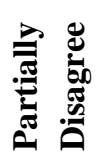 & 䲶 & 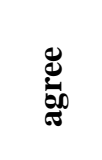 & 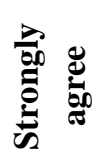 & 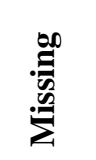 & 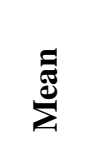 & 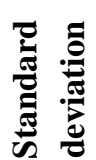 \\
\hline We carry our regular search & $\begin{array}{c}13 \\
3.3 \%\end{array}$ & $\begin{array}{c}17 \\
4.3 \%\end{array}$ & $\begin{array}{c}28 \\
7.2 \%\end{array}$ & $\begin{array}{c}82 \\
21.0 \%\end{array}$ & $\begin{array}{c}174 \\
44.5 \%\end{array}$ & $\begin{array}{c}77 \\
19.7 \%\end{array}$ & $\begin{array}{c}0 \\
0.0 \%\end{array}$ & 4.58 & 1.202 \\
\hline $\begin{array}{l}\text { We evaluate our market at } \\
\text { different times }\end{array}$ & $\begin{array}{c}4 \\
1.0 \%\end{array}$ & $\begin{array}{c}12 \\
3.1 \%\end{array}$ & $\begin{array}{c}99 \\
25.3 \%\end{array}$ & $\begin{array}{c}106 \\
27.1 \%\end{array}$ & $\begin{array}{c}117 \\
29.9 \%\end{array}$ & $\begin{array}{c}53 \\
13.6 \%\end{array}$ & $\begin{array}{c}0 \\
0.0 \%\end{array}$ & 4.23 & 1.123 \\
\hline $\begin{array}{l}\text { We use all tools available to } \\
\text { seek new opportunities }\end{array}$ & $\begin{array}{c}4 \\
1.0 \%\end{array}$ & $\begin{array}{c}36 \\
9.2 \%\end{array}$ & $\begin{array}{c}39 \\
10.0 \%\end{array}$ & $\begin{array}{c}38 \\
21.2 \%\end{array}$ & $\begin{array}{c}134 \\
34.3 \%\end{array}$ & $\begin{array}{c}95 \\
24.3 \%\end{array}$ & $\begin{array}{c}0 \\
0.0 \%\end{array}$ & 4.51 & 1.271 \\
\hline $\begin{array}{l}\text { Competitor evaluation is done } \\
\text { regularly }\end{array}$ & $\begin{array}{c}7 \\
1.8 \%\end{array}$ & $\begin{array}{c}28 \\
7.2 \%\end{array}$ & $\begin{array}{c}77 \\
19.7\end{array}$ & $\begin{array}{c}115 \\
29.4 \%\end{array}$ & $\begin{array}{c}119 \\
30.4\end{array}$ & $\begin{array}{c}45 \\
11.5 \%\end{array}$ & $\begin{array}{c}0 \\
0.0 \%\end{array}$ & 4.14 & 1.180 \\
\hline $\begin{array}{l}\text { We have a mechanism in place } \\
\text { to manage threats }\end{array}$ & $\begin{array}{c}4 \\
1.0 \%\end{array}$ & $\begin{array}{c}33 \\
8.4 \%\end{array}$ & $\begin{array}{c}84 \\
21.5 \%\end{array}$ & $\begin{array}{c}119 \\
30.4 \%\end{array}$ & $\begin{array}{c}122 \\
31.2 \%\end{array}$ & $\begin{array}{c}29 \\
7.4 \%\end{array}$ & $\begin{array}{c}0 \\
0.0 \%\end{array}$ & 4.05 & 1.120 \\
\hline $\begin{array}{l}\text { Average of Mean/ Standard } \\
\text { Deviation }\end{array}$ & & & & & & & & 4.302 & 1.179 \\
\hline
\end{tabular}

The responses in Table 1 revealed that the mean responses to question items on environmental scanning of the selected SMEs ranged from 4.05 to 4.60 with 4.3 as the grand mean response. On a six-point Likert scale, since this mean falls between 4.00 and 4.50 , it is interpreted as high meaning that the level of environmental scanning in the selected SMEs were considered high by the respondents.

Table 2: Descriptive Statistics on Market Share

\begin{tabular}{|c|c|c|c|c|c|c|c|c|c|}
\hline Items & 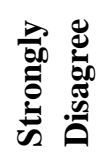 & 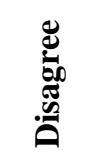 & 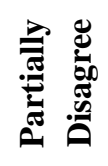 & 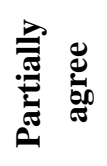 & 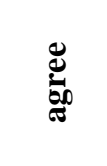 & 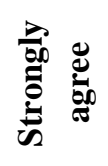 & 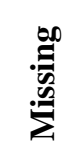 & $\stackrel{\Xi}{\Xi}$ & 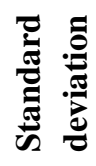 \\
\hline $\begin{array}{l}\text { We have a good position in the } \\
\text { market }\end{array}$ & $\begin{array}{c}10 \\
2.6 \%\end{array}$ & $\begin{array}{c}20 \\
5.1 \%\end{array}$ & $\begin{array}{c}12 \\
3.1 \%\end{array}$ & $\begin{array}{c}83 \\
21.2 \%\end{array}$ & $\begin{array}{c}184 \\
47.1 \%\end{array}$ & $\begin{array}{c}82 \\
21.0 \%\end{array}$ & $\begin{array}{c}0 \\
0.0 \%\end{array}$ & 4.68 & 1.147 \\
\hline $\begin{array}{l}\text { We have excellent customer } \\
\text { service }\end{array}$ & $\begin{array}{c}10 \\
2.6 \%\end{array}$ & $\begin{array}{c}15 \\
3.8 \%\end{array}$ & $\begin{array}{c}104 \\
26.6 \%\end{array}$ & $\begin{array}{c}123 \\
31.5 \%\end{array}$ & $\begin{array}{c}76 \\
19.4 \%\end{array}$ & $\begin{array}{c}63 \\
16.1 \%\end{array}$ & $\begin{array}{c}0 \\
0.0 \%\end{array}$ & 4.10 & 1.218 \\
\hline $\begin{array}{l}\text { Our revenue compared to } \\
\text { competitors is high }\end{array}$ & $\begin{array}{c}7 \\
1.8 \%\end{array}$ & $\begin{array}{c}33 \\
8.4 \%\end{array}$ & $\begin{array}{c}45 \\
11.8 \%\end{array}$ & $\begin{array}{c}105 \\
26.9 \%\end{array}$ & $\begin{array}{c}154 \\
39.4 \%\end{array}$ & $\begin{array}{c}46 \\
11.8 \%\end{array}$ & $\begin{array}{c}0 \\
0.0 \%\end{array}$ & 4.29 & 1.184 \\
\hline $\begin{array}{l}\text { Our growth compared to } \\
\text { competitors is high }\end{array}$ & $\begin{array}{c}10 \\
2.6 \%\end{array}$ & $\begin{array}{c}29 \\
7.4 \%\end{array}$ & $\begin{array}{c}80 \\
20.5 \%\end{array}$ & $\begin{array}{c}99 \\
25.3 \%\end{array}$ & $\begin{array}{c}136 \\
34.8 \%\end{array}$ & $\begin{array}{c}37 \\
9.5 \%\end{array}$ & $\begin{array}{c}0 \\
0.0 \%\end{array}$ & 4.11 & 1.204 \\
\hline $\begin{array}{l}\text { We have a vested interest in } \\
\text { emerging markets }\end{array}$ & $\begin{array}{c}5 \\
1.3 \%\end{array}$ & $\begin{array}{c}37 \\
9.5 \%\end{array}$ & $\begin{array}{c}81 \\
20.7 \%\end{array}$ & $\begin{array}{c}121 \\
30.9 \%\end{array}$ & $\begin{array}{c}108 \\
27.6 \%\end{array}$ & $\begin{array}{c}39 \\
10.0 \%\end{array}$ & $\begin{array}{c}0 \\
0.0 \%\end{array}$ & 4.04 & 1.174 \\
\hline $\begin{array}{l}\text { Average of Mean/ Standard } \\
\text { Deviation }\end{array}$ & & & & & & & & 4.24 & 1.185 \\
\hline
\end{tabular}

Source: Field Survey Result (2020)

The responses in Table 2 revealed that the mean responses to question items on market share of the selected SMEs ranged from 4.00 to 4.70 with 4.24 as the grand mean response. On a six-point Likert scale, since this mean falls between 4.00 and 4.70 , it is interpreted as high meaning that the level of market share in the selected SMEs were considered high by the respondents.

Combining the descriptive statistics of Tables 1 and 2, the responses indicate that it is possible for environmental scanning to influence market share of SMEs in Lagos state, Nigeria.

The inferential analysis used in the study is the ordinary least square linear regression to determine the effect of environmental scanning on market share of SMEs in Lagos state, Nigeria. The results were as displayed in Table 3 
International Journal of Advances in Scientific Research and Engineering (ijasre), Vol 7 (4), April -2021

Table 3: Regression Result of Effect of Environmental Scanning on Market Share

\section{Coefficients}

\begin{tabular}{|c|c|c|c|c|c|c|c|}
\hline Model & $\boldsymbol{B}$ & $\boldsymbol{t}$ & $\boldsymbol{S i g}$. & $\boldsymbol{R}$ & $\boldsymbol{R}^{\mathbf{2}}$ & $\boldsymbol{F}_{(\mathbf{1}, \mathbf{3 8 9})}$ & $\boldsymbol{F}($ Sig. $)$ \\
\hline (Constant) & 10.177 & 9.797 & 0.000 & 0.480 & 0.230 & 116.246 & $0.000^{\mathrm{b}}$ \\
\hline Environmental Scanning & 0.513 & 10.782 & 0.000 & & & & \\
\hline
\end{tabular}

a. Dependent Variable: Market Share

b. Predictors: (Constants), Environmental Scanning

\section{Source: Field Survey Result (2021)}

Table 4.6 presents the result of a simple linear regression test to establish the effect of environmental scanning on market share. The results obtained for this analysis include $\left(\beta=0.513, \mathrm{R}=0.480, \mathrm{R}^{2}=0.230, \mathrm{t}=10.782, \mathrm{p}<0.05\right)$. The result revealed that environmental scanning has a positive and significant effect on market share. The $\beta$ shows that a unit increase in environmental scanning leads to 0.513 units increase in market share of selected SMEs in Lagos State, Nigeria. The R $=0.480$ shows there is a positive linear relationship between environmental scanning and market share. The $\mathrm{R}^{2}$ which is referred to as coefficient of determination is given as 0.230 . This implies that $23 \%$ of the changes or variation in market share can be accounted for by environmental scanning. However, the remaining unexplained $77 \%$ variance could be attributed to other factors that was not considered in this study. The $\mathrm{p}$ value of 0.000 indicates that the overall model is statistically significant. From the unstandardized coefficients, the regression model can be formulated, which help to form the line of best will fit for the analysis. The initial model was given as $y_{1}=a_{0}+\beta_{1} x+$ ei.

The regression model of environmental scanning on market share is expressed as:

$\mathrm{MS}=10.177+0.513 \mathrm{ES}$ Eq. (i)

\section{DISCUSSION}

The study evaluated the effect of environmental scanning on market share. The results of the regression analysis for the effect of environmental scanning on market share of selected SMEs in Lagos State, Nigeria provided an overall significant view. The combination of the dependent and independent variables was statistically significant in showing environmental scanning have effects on market share of the selected SMEs in Lagos State, Nigeria

The study is consistent with empirical findings of Babtunde and Adebisi (2012), in their study of strategic environment scanning, and organisational performance and the findings show a significant positive relationship between environmental scanning and corporate survival, the researcher recommends that organisation should strategically, periodically, and continuously involve in strategic environmental scanning and pay strong attention to the threats (to avoid) and opportunities (to seize) in the environment [24]. The findings of Gupta (2013) established that there is a strong relationship between the business environment and the survival of the organisation. Therefore, the study posits that this area should be well tackled to keep an organisation on an excellent platform to survive [30]. Furthermore, Gupta (2013), in his study of the environment and PEST analysis: an approach to the external business environment, established that environmental scanning has an impact on organisational survival [30]. The theoretical evidence of the effect of environmental scanning on market share is evident in Dynamic capabilities theory (DCT). The theory emphasis is devoted to addressing the continuous renewal of administrative capabilities, by accurately matching the demands to the rapidly changing environments.

\section{CONCLUSION AND RECOMMENDATION}

This study concluded that environmental scanning plays an important role in enhancing the market share of selected small and medium scale enterprises (SMEs) in Lagos State, Nigeria. The result showed that environmental scanning has significant effect on market share of selected small and medium scale enterprise in Lagos State, Nigeria. The study recommends that the management team of the selected SMEs should ensure they adopt and implement proper environmental scanning to increase their market share. Further researchers could employ longitudinal survey research design to capture the dynamics of organisational factors and performance. 


\section{REFERENCE}

1. Neneh, B. N., \& Van zyl, J. (2014). Achieving optimal business performance through business practices: evidence from SMEs in selected areas in South Africa. Southern Africa Review, 16(3), 118-144.

2. Durguner, S. (2017). Do borrower-lender relationships still matter for small business loans? Journal of International Financial Markets, Institutions and Money, 50, 98-118.

3. Kotane, I., \& Kuzmina-Merlino, I. (2017). Analysis of Small and Medium Sized Enterprises' Business Performance Evaluation Practice at Transportation and Storage Services Sector in Latvia. Procedia Engineering, 178, $182-191$.

4. Melnichuk, M. V. (2017). Foreign experience of regulation of small business development and its application in Russian reality. Problems of economics and legal practice, 2, 18-21.

5. Herath, H. A., \& Mahmood, R. (2013). Strategic orientation-based research model of SME performance for developing countries. Review of Integrative Business and Economics Research, 2(1), 430.

6. Rohrbeck, R., \& Kum, M. E. (2018). Corporate organisational factors and its impact on firm performance: A longitudinal analysis. Technological Forecasting and Social Change, 129, 105-116.

7. Spacek, D., \& Gatarik, E. (2017). Knowledge Management and Czech Self-Governments: Empirical Investigations into the Application of Knowledge Management to Public Administration in the Czech Republic. NISPAcee Journal of Public Administration and Policy, 10(1), 201-220.

8. Nuryakin, U. M. (2016). Competitive Advantage and Product Innovation: Key Success of Batik SMES Marketing Performance in Indonesia. Academy of Strategic Management Journal, 17, 1.

9. Gbandi, E. C., \& Amissah, G. (2014). Financing options for small and medium enterprises (SMEs) in Nigeria. European Scientific Journal, 10(1).

10. Tahir, F. A., \& Usman, F. I. (2019). Empirical Investigation of the Factors Affecting Micro, Small and Medium Scale Enterprises Performance in Borno State, Nigeria. International Business Research, 12(4), 30-39.

11. Amuda, Y. J. (2020). Impact of coronavirus on small and medium enterprises (smes): towards post-covid-19 economic recovery in Nigeria. Academy of Strategic Management Journal, 19(6), 1-9.

12. Onodugo, V. A. \& Ewurum, U. J. F. (2013). Environmental Scanning: An Imperative for business survival and growth in Nigeria. Journal of Economics and Sustainable Development 4(7), 12-20.

13. Oginni, B. O. \& Adesanya, A. S. (2013). Business Environmental Factors: Implications on the Survival and Growth of Business Organisations in the Manufacturing Sector of Lagos Metropolis. Business and Management Research, 2 (3), 146.

14. Olanipekun, W. D., Abioro, M. A., Akanni, L. F., Arulogun, O. O., \& Rabiu, R. O. (2015). Impact of Strategic Management on Competitive Advantage and Organisational Performance - Evidence from Nigerian Bottling Company. Journal of Policy and Development Studies, 9(2), 185-198.

15. Agwu, M. O., \& Emeti, C. I. (2014). Issues, challenges and prospects of small and medium scale enterprises (SMEs) in Port-Harcourt City, Nigeria. European Journal of Sustainable Development, 3(1), 101-114.

16. Awiti, L. H., Oloko, M., \& Rambo, C. (2017). Influence of Environmental Scanning on Performance of HIV and AIDS Interventions Managed by Nongovernmental Organisations in Nyanza Region. International Journal of Academic Research in Business and Social Sciences, 7(2), 126-144.

17. Ukpabio, M.G., Oyebisi, T.O. \& Siyanbola, O.W. (2019). Effects of Innovation on Performance of Manufacturing SMEs in Nigeria: An empirical study. Retrieved on 21/09/2019 from http://liee.ntua.gr/wp-content/uploads/2018/02/879-Effectsof-Innovation-on-Performance-of-Manufacturing-SMEs-.pdf.

18. Omodafe, U. P. \& Nwaizugbo, I. C. (2017). Innovative marketing and Performance of selected SMEs in Nigeria. International Journal of Small Business and Entrepreneurship Research, 5(3), 1-18.

19. Monye, M. C. \& Ibegbulem, A. B. (2018). Effect of Strategic Planning on Organisational Performance and Profitability. International Journal of Business \& Law Research, 6(2), 31-40,

20. Olugboyega, A.D. (2017). Entrepreneurial Creativity and Innovation: A Tool for Solving Economic Crisis in Nigeria. Covenant Journal of Entrepreneurship, 1(2), 20-31.

21. Borges, N., \& Janissek-Muniz, R. (2017). The Environmental Scanning as an Informal and Individual Practice in Organisations.

22. McLean, L. D. (2005). Organisational culture's influence on creativity and innovation: A review of the literature and implications for human resource development. Advances in Developing Human Resources, 7(2), 226-246.

23. Tapinos, E. (2012). Perceived Environmental Uncertainty in scenario planning. Futures, 44(4), 338-345.

24. Babatunde, B. O. \& Adebisi, A. O. (2012). Strategic Environmental Scanning and Organisation Performance in a Competitive Business Environment. Economic Insights - Trends and Challenges, 54(1), 24-34.

25. Bianchi, C. (2012) Introducing SD modelling into planning and control systems to manage SMEs' growth: a learningoriented perspective. System Dynamics Review, 18(3), 315-338.

26. Okolo, V. O. (2017). Evaluation of the Effects of Marketing Strategies on Consumer Patronage of Restaurants in Enugu (A Study of Mr. Bigg's). European Journal of Social Sciences, 55(3), 297-320. 
27. Woo, C. Y. \& Cooper, A. C. (2011). Strategies of Effective Low Share Businesses. Strategic Management Journal, 2(3), 301-318.

28. Caves, R. \& Porter, M. E. (2010). From Entry Barriers to Mobility Barriers: Conjectural Decisions and Contrived Deterrence to New Competition. Quarterly Journal of Economics, 91(2), 241-262.

29. Éverton, L. P., Elton, J. B. J. \& Rossetto, C. R. (2014). Environmental scanning, strategic behavior and performance in small companies. Journal Information System and Technology Management, 11(3), 611-628.

30. Gupta, A. (2013) Environment \& PEST Analysis: An Approach to External Business Environment. International Journal of Modern Social Sciences, 2(1), 34-43.

31. Teece, D. J., Pisano, G., \& Shuen, A. (1997). Dynamic capabilities and strategic management. Strategic management journal, 18(7), 509-533.

32. Teece, D. J. (2007). Explicating dynamic capabilities: the nature and micro foundations of (sustainable) enterprise performance. Strategic Management Journal, 28(13), 1319-1350.

33. Kaplan, S., \& Orlikowski, W. J. (2013). Temporal work in strategy making. Organisation Science, $24(4), 965-995$.

34. Gavetti, G. (2012). Toward a behavioral theory of strategy. Organisation Science, 23(1), 267-285.

35. Gavetti, G., \& Menon, A. (2016). Evolution cum agency: Toward a model of organisational factors. Strategy Science, $1(3), 207-233$. 